\title{
Avian community response to fire and mechan- ical shrub control in south Florida
}

\author{
SUSAN M. FITZGERALD AND GEORGE W. TANNER
}

\begin{abstract}
Authors are wildlife biologist, U.S. Forest Service, Apalachicola National Forest, Crawfordville, Florida. 32327 and associate professor, Wildlife and Range Sciences, University of Florida, Gainesville 32611. At the time of the research, the senior author was graduate research assistant, Wildlife and Range Sciences, University of Florida.
\end{abstract}

\begin{abstract}
Effects of prescribed fire and roller chopping applied in 2 seasons on woody vegetation and the associated avian community of a southwestern Florida former dry prairie were studied. There were 5 vegetation treatments with 2 replications of each; treatments were control, winter burn, winter chop, summer burn, and summer chop. Percent shrub cover was sampled with line intercept transects. Birds were censused 25 times using the variable circular plot method. Burning in either season reduced shrub cover temporarily; chopping in either season reduced shrub cover significantly and it remained reduced throughout the 15 months of this study. Bird species richness and abundance were similar in control and burn plots. Birds were not seen in summer chop plots up to 5 months posttreatment. Bird species richness and abundance remained low in both winter and summer chop plots. Bird species that were observed in chop plots were mostly open country, grassland inhabitants, indicating a trend toward prairie restoration.
\end{abstract}

Key Words: south Florida prairie restoration, seasonal roller chopping, seasonal prescribed burning, bird responses

Dry prairie grasslands in Florida have been described as "vast, treeless plains, often intermediate between wet grassy areas and the forested uplands"(Kale 1978, p. xii), or as South Florida flatwoods with "few, if any, trees" (Soil Conservation Service 1989, p. 34). The plant community is dominated by grasses, and saw-palmetto (Serenoa repens (Bartr.) Small) is the most common shrub. This type of prairie is endemic to southern Florida, and its ecological integrity formerly was maintained by frequent and extensive lightning-caused fires ignited mostly from late May through July. Traditional ranching practices in this region have typically included prescribed fire during January or February just prior to spring initiation of plant growth.

Approximately 35 years of fire suppression in one of Florida's largest state parks, Myakka River State Park, has resulted in shrub dominance of the former dry prairie grasslands located within the park. Land surveyors in the 1700 and 1800 's described this area as a grass-dominated prairie with low, sparse saw-palmetto and scattered cabbage palms (Sabal palmetto (Walt.) Lodd. ex Schultes). Florida Department of Natural Resources'goal in natural resource management is to maintain or restore state parks as representative samples of original Florida. Therefore, the goal of prairie restoration within Myakka River State Park involves reduction of shrub cover to allow grasses and other herbaceous plants to dominate (Myakka River State Park Unit Plan 1986). Fire alone may not be sufficient to restore these shrub-dominated former grasslands. Mechanical methods, such as rolling chopping, may provide a fast,

Research was funded by Florida Game and Fresh Water Fish Commissions Nongame Program. This manuscript is Florida Agricultural Experiment Station Journal Series Article R-01871.

Manuscript accepted 19 Oct. 1991 effective first step in rehabilitation.

Changes in the vegetative community composition and physiognomic structure most probably will result in an altered avian community (Anderson 1980, Johnston and Odum 1956). It is not known what changes the current shrub dominance of former dry prairie grasslands has caused in the bird community. Birds are recognized as indicators of habitat conditions (Bock and Webb 1984, Szaro and Balda 1982). This study examined the immediate and short-term responses of bird and shrub communities to the attempted rehabilitation of a former dry prairie in southwestern Florida. Documentation of the effects on these communities of fire and roller chopping applied in 2 seasons will provide information applicable to the development of future land management strategies.

\section{Study Area and Methods}

The study area is a former dry prairie grassland located in the Myakka River State Park. The park is in Sarasota and Manatee Counties in southwestern Florida, and is 11,686 ha in size with approximately 6,500 ha of what once was dry prairie. Elevation of the prairie areas is from 10.7 to $12.2 \mathrm{~m}$ above msl. Soils are mostly a Myakka-Immokalee-Basinger Association (sandy, siliceous, hyperthermic, Aeric and Arenic Haplaquods and Spodic Psammaquent, respectively) overlying an organic hardpan or clayey subsoil. The climate of this area is characterized by mild, dry winters and hot, wet summers. Average annual precipitation is $1,440 \mathrm{~mm}$, and approximately $60 \%$ occurs between June and September. Ambient temperatures during this study ranged from -5.5 to $37.2^{\circ} \mathrm{C}$.

Eight treatment plots were established in an area previously unburned for 12 to 15 years until burned by wildfire on 13 May 1986. Two nearby areas that had not been burned during the past 15 years served as controls. Each plot was approximately 6.1 ha and separated by plowed fire lanes. Treatments were a winter burn, a winter chop, a summer burn, and a summer chop. Two replicates were obtained for each treatment and a control. Winter burn and winter chop treatments were installed in January 1988, summer burns in late June 1988 and summer chops in July 1988. All prescribed burns were headfires. Chopping was accomplished with a single pass of Marden M-7 ${ }^{\circledR}$ drum choppers pulled in tandem by a rubber-tire tractor.

Woody plant canopy cover was measured using the line intercept method (Canfield 1941). Eight, 30-m transects were located randomly within each plot. The length of the transect line that intercepted the plant canopy of each shrub species was measured. Due to layering of different species, shrub cover could be greater than $100 \%$. Each line transect was subdivided into 3, 10-m segments; height of the first plant encountered of each shrub species on each segment was measured. Shrub cover was sampled during May, July, and October, 1988, and January and April, 1989.

Birds were censused 25 times in each plot, using the variable circular plot method (Reynolds et al. 1980, Szaro and Balda 1982), from July, 1988 to April, 1989. Each treatment plot and the con- 
Table 1. Mean (SD) species richness of shrubs per 30-m transect line measured during 5 sampling periods at Myakka River State Park. Means did not differ among treatments (ANOVA, $P>0.05$ ).

\begin{tabular}{|c|c|c|c|c|c|}
\hline \multirow[b]{2}{*}{ Treatment $^{1}$} & \multicolumn{5}{|c|}{ Sample Date } \\
\hline & May 1988 & Jul 1988 & Oct 1988 & Jan 1989 & Apr 1989 \\
\hline $\begin{array}{l}\text { Control } \\
\text { Winter burn } \\
\text { Winter chop } \\
\text { Summer burn } 2 \\
\text { Summer chop }{ }^{2}\end{array}$ & $\begin{array}{l}6.6(1.4) \\
6.0(1.5) \\
6.1(1.2)\end{array}$ & $\begin{array}{l}5.8(1.6) \\
7.2(1.6) \\
7.9(1.4)\end{array}$ & $\begin{array}{l}5.0(1.9) \\
7.1(1.6) \\
7.4(1.3) \\
5.9(1.4) \\
5.8(1.1)\end{array}$ & $\begin{array}{l}5.2(1.9) \\
6.8(1.3) \\
7.3(1.3) \\
6.5(1.7) \\
6.9(1.4)\end{array}$ & $\begin{array}{l}5.8(2.4) \\
7.1(1.4) \\
7.4(1.7) \\
6.7(1.7) \\
6.4(0.9)\end{array}$ \\
\hline
\end{tabular}

'Linear regression of species richness over time: richness $[C]=6.3-0.2$ (time), $P=0.1370, R^{2}=0.03$; richness $[W B]=6.3+0.2$ (time), $P=0.1534, R^{2}=0.03 ;$ richness $[W C]=6.7+0.2$ (time), $P=0.1110, R^{2}=0.03$; richness $[S B]=5.5+0.4$ (time), $P=0.1576, R^{2}=0.04 ;$ richness $[S C]=5.7+0.3$ (time), $P=0.1092, R^{2}=0.05$.

'Summer burn (SB) and Summer chop (SC) not sampled May 1988 and July 1988.

trols contained 1 permanently marked bird census plot center. All birds seen or heard were recorded for $\mathbf{1 0}$ minutes, with sampling beginning as soon as the observer reached the center of the census plot. Birds were counted from approximately 10 minutes before sunrise up to 3 hours after sunrise. The sequence of plot visitation was rotated randomly to reduce temporal bias.

To determine differences among treatments within a sampling period, data were analyzed using a general linear model for analysis of variance (ANOVA) (Statistical Analysis Institute 1986). A nested design with treatment as the main units and plots as the subunits was used to analyze the vegetation data. Bird censuses were analyzed 2 ways: using repeated measures ANOVA and also a randomized block design. When a significant treatment effect $(P<0.05)$ was detected with ANOVA, the Waller-Duncan mean separation procedure was used to determine which treatments were different. Regression analysis was applied to the vegetation data to determine if there were changes within treatment groups over time. The independent variable "time" in the regression equations is the number of months since treatment application. Shrub cover, shrub height, shrub species richness (mean number of species per $30-\mathrm{m}$ transect line) were square-root transformed to normalize the data. Bird data were not transformed. All tabular data are actual mean values.

\section{Results}

\section{Habitat Modification}

A total of 26 shrub species, or species groups, was encountered during this study. Saw-palmetto was the dominant shrub species in all treatments and all sampling periods, averaging over $50 \%$ of the total shrub cover. Gallberry (Ilex glabra (L.) A. Gray), wax myrtle (Myrica cerifera L.), ground blueberry (Vaccinium myrsinites Lam.), runner oaks (Quercus pumila Walt. and Q. minima (Sarg.) Small), and lyonia (Lyonia lucida (Lam.) D. Don and L. fruticosa (Michx.) Torr.) comprised the next 5 most dominant species or species groups in each respective treatment, but varied in order of dominance in the different treatments and different sampling periods. However, none of these species ever exceeded $20 \%$ of the total shrub cover.
Shrub species richness varied little among the 4 treatments and the control. Means ranged from 5.0 (control, October 1988) to 7.9 species per transect (winter chop, July 1988) (Table 1). Burned or chopped plots tended to have slightly higher species richness than control plots, but there were no significant differences among treatment means. Species richness within treatments did not change significantly over time.

Total shrub cover was significantly different among the treatments during each sampling date (Table 2). Control plots consistently had the highest percent cover, the grand average greater than $100 \%$. By January 1989 , however, total shrub cover for control plots was not significantly higher than that for winter burn plots, due to regrowth of shrubs after burn treatment. Total shrub cover was significantly lower, by approximately one-half, for chopped plots than for burned plots following the winter and summer treatments. Shrub cover increased steadily following both types of treatments. Regression analyses indicated that for all treatments the slope was positive and significantly different from zero. By April 1989, differences in shrub cover between winter burn plots and summer burn plots and between winter chop plots and summer chop plots were not significant, although there was 6 months difference in regrowth time between winter and summer treatments.

Shrub heights in control plots were significantly taller than in all other treatment plots in all sampling periods (Table 3). Although differences in shrub height between winter burn plots and winter chop plots and between summer burn plots and summer chop plots were not significant, mean shrub heights in burned plots tended to be greater, but with a larger degree of variation, than in chopped plots. The increases in shrub height over time were significant for winter burn and winter chop plots.

\section{Birds}

Maximum detection distances varied among bird species. For small species such as common yellowthroat (Geothlypis trichas (L.)) and Bachman's sparrow (Aimophilia aestivalis (Lichtenstein)), detection distances were determined to be $35-40 \mathrm{~m}$; for larger species, detection distances were $50-55 \mathrm{~m}$. We chose $40 \mathrm{~m}$ as the limit. This $40-\mathrm{m}$ radius limit may have resulted in underestima-

Table 2. Mean (SD) percent shrub cover measured during during 5 sampling periods at Myakka River State Park. For each sample date, values followed by the same letter are not significantly different $(P>0.05$, Waller-Duncan test).

\begin{tabular}{|c|c|c|c|c|c|}
\hline \multirow[b]{2}{*}{ Treatment $^{1}$} & \multicolumn{5}{|c|}{ Sample Date } \\
\hline & May 1988 & Jul 1988 & Oct 1988 & Jan 1989 & Apr 1989 \\
\hline $\begin{array}{l}\text { Control } \\
\text { Winter burn } \\
\text { Winter chop } \\
\text { Summer burn² } \\
\text { Summer chop }\end{array}$ & $\begin{array}{l}94.0(13.9)^{\mathrm{a}} \\
34.2(11.3)^{\mathrm{b}} \\
14.5(2.4)^{\mathrm{c}}\end{array}$ & $\begin{array}{r}103.1(11.7)^{a} \\
57.7(13.4)^{b} \\
25.4(5.8)^{c}\end{array}$ & $\begin{array}{c}105.5^{a}(11.5)^{a} \\
74.1(13.1)^{b} \\
34.3(7.6)^{c} \\
50.0(8.0)^{c} \\
18.9(8.2)^{d}\end{array}$ & $\begin{array}{c}103.6(10.2)^{\mathrm{a}} \\
80.9(14.6)^{\mathrm{ab}} \\
37.7(7.0)^{\mathrm{c}} \\
65.1(8.2)^{\mathrm{b}} \\
27.5(11.6)^{\mathrm{c}}\end{array}$ & $\begin{array}{c}103.3(10.6)^{\mathrm{a}} \\
82.5(15.6)^{\mathrm{ab}} \\
34.3(6.5)^{\mathrm{c}} \\
71.0(9.5)^{\mathrm{b}} \\
28.7(10.3)^{\mathrm{c}}\end{array}$ \\
\hline
\end{tabular}

'Linear regression of shrub cover over time: cover $[C]=9.8+0.1$ (time), $P=0.0228, R^{2}=0.06 ;$ cover[WB] $=5.6+0.8\left(\right.$ time), $P=0.0001, R^{2}=0.57 ; \operatorname{cover}[W C]=3.7+0.5($ time), $P=0.0001$, $\mathrm{R}^{2}=0.56$; cover $[\mathrm{SB}]=6.4+0.7$ (time), $P=0.0001, \mathrm{R}^{2}=0.51 ;$ cover $[\mathrm{SC}]=3.9+0.5$ (time), $P=0.0052, \mathrm{R}^{2}=0.14$.

${ }^{2}$ Summer burn (SB) and Summer chop (SC) not sampled May 1988 and July 1988. 
Table 3. Mean (SD) shrub height in cm measured during 5 sampling periods at Myakka River State Park. For each sample date, values followed by the same letter are not significantly different $(P>0.05$, Waller-Duncan test).

\begin{tabular}{|c|c|c|c|c|c|}
\hline \multirow[b]{2}{*}{ Treatment ${ }^{1}$} & \multicolumn{5}{|c|}{ Sample Date } \\
\hline & May 1988 & Jul 1988 & Oct 1988 & Jan 1989 & Apr 1989 \\
\hline $\begin{array}{l}\text { Control } \\
\text { Winter burn } \\
\text { Winter chop } \\
\text { Summer burn } 2 \\
\text { Summer chop }\end{array}$ & $\begin{array}{l}99.2(25.2)^{\mathrm{a}} \\
33.0(6.2)^{\mathrm{b}} \\
24.5(3.6)^{\mathrm{b}}\end{array}$ & $\begin{array}{c}108.6(30.7)^{\mathrm{a}} \\
33.0(8.2)^{\mathrm{b}} \\
28.6(3.1)^{\mathrm{b}}\end{array}$ & $\begin{array}{c}123.5(34.3)^{\mathrm{a}} \\
37.0(11.0)^{\mathrm{b}} \\
30.1(4.7)^{\mathrm{b}} \\
28.2(3.5)^{\mathrm{bc}} \\
22.4(3.8)^{\mathrm{c}}\end{array}$ & $\begin{array}{c}111.0(37.8)^{\mathrm{a}} \\
37.8(10.4)^{\mathrm{b}} \\
29.7(3.7)^{\mathrm{bc}} \\
27.8(5.1)^{\mathrm{bc}} \\
20.6(3.9)^{\mathrm{c}}\end{array}$ & $\begin{array}{c}100.9(27.7)^{\mathrm{a}} \\
38.8(10.2)^{\mathrm{b}} \\
30.6(3.6)^{\mathrm{bc}} \\
29.2(3.5)^{\mathrm{bc}} \\
22.6(3.5)^{\mathrm{c}}\end{array}$ \\
\hline
\end{tabular}

'Linear regression of shrub height over time: height $[C]=10.3+0.02$ (time), $P=0.8623, R^{2}=0.0$; height $[W B]=5.5+0.1$ (time), $P=0.0220, R^{2}=0.07 ;$ height $[W C]=5.0+0.1$ (time), $P=0.0001, R^{2}=0.19 ;$ height $[S B]=5.2+0.05$ (time), $P=0.4751, R^{2}=0.01 ;$ height $[S C]=4.6+0.01$ (time), $P=0.8697, R^{2}=0.0$

2Summer burn (SB) and Summer chop (SC) not sampled May 1988 and July 1988.

tion of bird use. However, this underestimation was consistent on all plots so comparison among plots was valid, but absolute density estimates were likely not valid.

On the entire study site, 47 species of birds were identified (Table 4), including species observed during censuses, those outside the chosen detection distance, and those seen at other times on the study site. In 25 censuses, 27 species of birds were counted (Table

Table 4. List of bird species observed on entire study area at Myakka River State Park, July 1988 to April 1989.

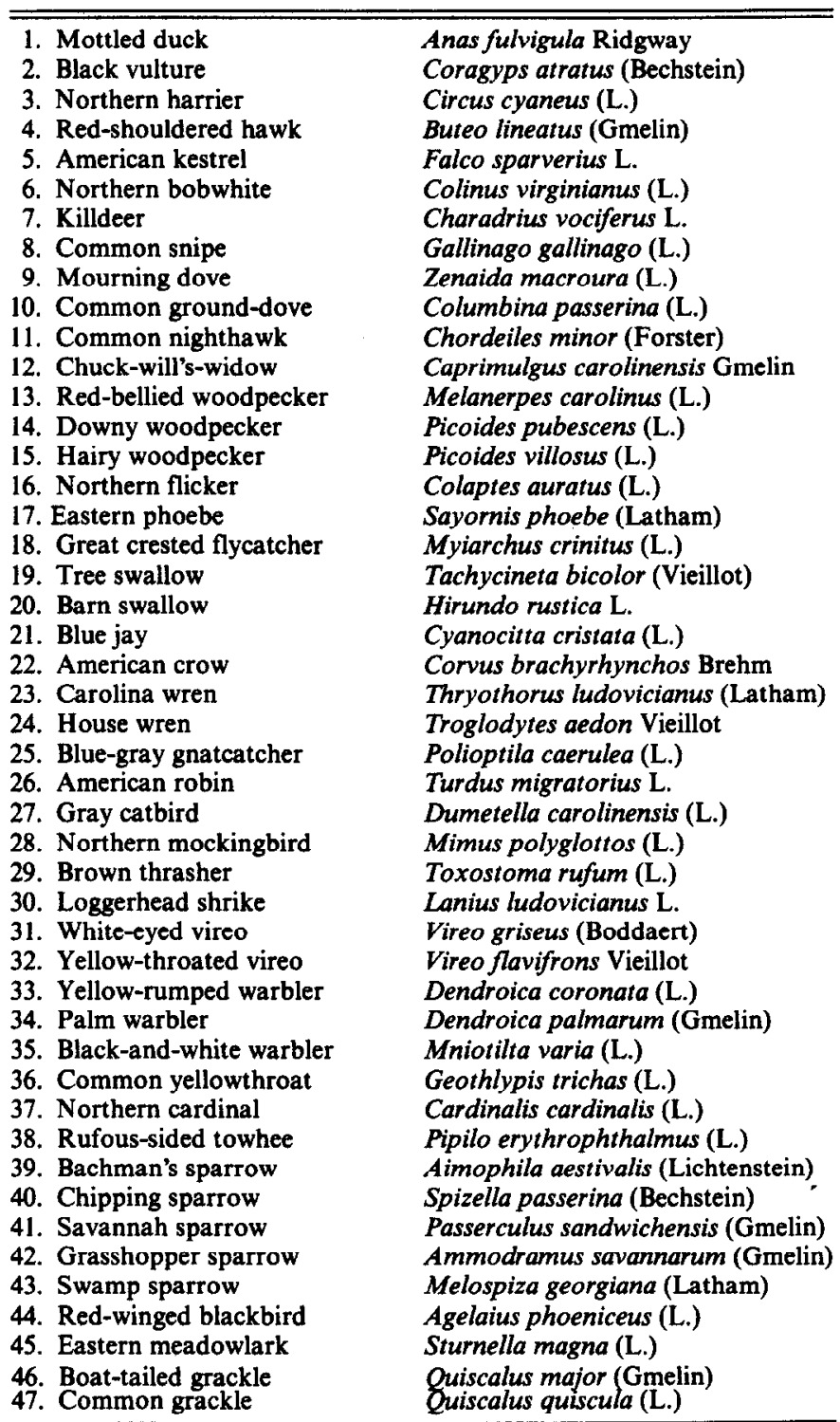

5). Ten species occurred just once. There also were categories for unknown birds, unknown sparrows, and unknown warblers. Repeated measures ANOVA on the number of individuals and the number of bird species indicated that treatment had a significant effect. When analyzing these same data in a randomized block design, with months as the blocking factor, main effects of treatment and month were significant, but the only 2 months that were different were August 1988 and March 1989. This probably was due to the presence of migrants, mostly warblers, in March.

The mean number of individuals and mean number of bird species in the winter and summer burns were not different. (Table 6) Bird abundance in the winter burn treatment was not different from control plots, but the summer burn treatment had lower bird abundance than controls during this sampling period. Bird abundance in both winter and summer chops were significantly lower than in controls and burn treatments.

\section{Discussion}

Other studies on shrub cover reduction using roller chopping in different seasons had various results: 2 studies suggested double chopping worked best in the dry season when soil moisture was low (Hilmon et al. 1963, Moore 1974); 1 study indicated season did not appear to have a significant effect, probably because soil moisture was low in both seasons (Kalmbacher and Martin 1984); and another indicated single chopping worked best in the wet season when soils were saturated (Tanner et al. 1988). Soil moisture has been postulated to influence chopping efficiency. Rainfall at Myakka River State Park in December 1987 and January 1988 was approximately normal $(118.9 \mathrm{~mm}$ fell, $119.9 \mathrm{~mm}$ is normal for this 2 -month period). However, in May and June 1988, rainfall was approximately $161.0 \mathrm{~mm}$ below normal (148.1 $\mathrm{mm}$ fell, $309.1 \mathrm{~mm}$ is normal for this 2-month period) (NOAA 1987, NOAA 1988). During the 5 days before winter and summer chopping, $51.1 \mathrm{~mm}$ and $29.2 \mathrm{~mm}$ of rain, respectively, were recorded approximately $2.5 \mathrm{~km}$ from the study site. It appears soil moisture was low in both seasons, which may have led to no detectable seasonal differences in treatment efficacy for shrub cover reduction. When comparing chopped plots to control plots, season of treatment appeared to have no effect but chopping in either season reduced overall shrub cover, and it remained reduced throughout the duration of the study. Other studies have shown chopping to be effective for shrub cover reduction with effects persisting for 2 to 5 years after treatment (Lewis 1970, Moore 1974, Tanner et al. 1988).

Summer fires have been suggested to be more effective than winter fires for reducing shrub cover (Grelen 1975, Hughes and Knox 1964, Langdon 1981, Waldrop et al. 1987), but these conclusions were usually based on repeated fires over many years. Sporadic or infrequent fires do not appear to have much effect when applied in summer or winter. In this study, total shrub cover in winter burn plots was not different from that measured in control plots just 12 months after burning. Shrub cover following 2 fires ( 1 
Table 5. Bird species frequency of occurrence and total abundance in a 40 -m radium in 25 censuses conducted from July 1988 to April 1989 at Myakka River State Park.

\begin{tabular}{|c|c|c|c|c|c|c|c|c|c|c|}
\hline & \multicolumn{2}{|c|}{ Control } & \multicolumn{2}{|c|}{ Winter burn } & \multicolumn{2}{|c|}{ Winter chop } & \multicolumn{2}{|c|}{ Summer burn } & \multicolumn{2}{|c|}{ Summer chop } \\
\hline & Freq. & Abund. & Freq. & Arund. & Freq. & Abund. & Freq. & Arund. & & \\
\hline Common Yellowthroat & 12 & 16 & 16 & 35 & 4 & 5 & 11 & 18 & & \\
\hline Rufous-sided towshee & 11 & 21 & 11 & 20 & & & 16 & 25 & & \\
\hline White-eyed vireo & 11 & 15 & & & & & & & & \\
\hline Carolina Wren & 10 & 13 & 3 & 3 & & & 1 & 2 & & \\
\hline Gray catbird & 10 & 11 & & & & & 1 & l & & \\
\hline Warbler spp. & 5 & 14 & & & & & & & & \\
\hline Northern cardinal & 5 & 6 & & & & & & & & \\
\hline Yellow-rumped warbler & 4 & 9 & 1 & 1 & 1 & 1 & & & & \\
\hline Palm Warbler & 4 & 11 & 4 & 10 & 2 & 3 & 6 & 14 & & \\
\hline Unknown spp. & 4 & 5 & 1 & 1 & 1 & 1 & 1 & 1 & & \\
\hline Northern Mockingbird & 3 & 3 & & & & & & & & \\
\hline Eastern phoebe & 1 & 1 & & & & & & & & \\
\hline American robin & $i$ & I & & & & & & & & \\
\hline Brown thrasher & 1 & 1 & & & & & & & & \\
\hline Yellow-throated vireo & 1 & 1 & & & & & & & & \\
\hline Blue-gray gnatcatcher & $i$ & 1 & & & & & & & & \\
\hline Swamp sparrow & 1 & $i$ & & & & & & & & \\
\hline Bachman's sparrow & & & 21 & 27 & 9 & 9 & 4 & 5 & 2 & 2 \\
\hline Eastern meadowlark & & & 8 & 11 & 19 & 27 & 4 & 7 & 5 & 7 \\
\hline Common ground-dove & & & 2 & 2 & 2 & 2 & 3 & 3 & & \\
\hline Northern bobwhite & & & $\overline{1}$ & 1 & 1 & 1 & 2 & 5 & & \\
\hline Loggerhead shrike & & & 1 & 1 & 1 & 1 & 4 & 4 & & \\
\hline Chipping sparrow & & & 1 & 1 & & & & & & \\
\hline $\begin{array}{l}\text { Red-winged blackbird } \\
\text { Red-bellied woodpecker }\end{array}$ & & & 1 & 1 & $\begin{array}{l}1 \\
2\end{array}$ & $\begin{array}{l}2 \\
2\end{array}$ & & & & \\
\hline Sparrow spp. & & & & & & & 4 & 4 & 1 & 1 \\
\hline Morning dove & & & & & & & 1 & 2 & & \\
\hline Northern flicker & & & & & & & 1 & 1 & & \\
\hline Savannah sparrow & & & & & & & 1 & 2 & & \\
\hline Grasshopper sparrow & & & & & & & 1 & 1 & & \\
\hline Yellow-throated vireo & 1 & 1 & & & & & & & & \\
\hline Blue-gray gnatcatcher & 1 & 1 & & & & & & & & \\
\hline Swamp sparrow & 1 & 1 & & & & & & & & \\
\hline Bachman's sparrow & & & 21 & 27 & 9 & 9 & 4 & 5 & 2 & 2 \\
\hline Eastern meadowlark & & & 8 & 11 & 19 & 27 & 4 & 7 & 5 & 7 \\
\hline Common ground-dove & & & 2 & 2 & 2 & 2 & 3 & 3 & & \\
\hline Northern bobwhite & & & 1 & 1 & 1 & 1 & 2 & 5 & & \\
\hline Loggerhead shrike & & & 1 & $i$ & i & 1 & 4 & 4 & & \\
\hline Chipping sparrow & & & $i$ & $i$ & & & & & & \\
\hline Red-winged blackbird & & & 1 & 1 & 1 & 2 & & & & \\
\hline Red-bellied woodpecker & & & & & 2 & 2 & & & & \\
\hline Sparrow spp. & & & & & & & 4 & 4 & 1 & 1 \\
\hline Morning dove & & & & & & & 1 & 2 & & \\
\hline Northern flicker & & & & & & & 1 & 1 & & \\
\hline Savannah sparrow & & & & & & & 1 & 2 & & \\
\hline Grasshopper sparrow & & & & & & & 1 & 1 & & \\
\hline
\end{tabular}

ISee Table 4 for scientific names

Table 6. Mean (SD) number of individuals and mean (SD) number of bird species counted in $40-\mathrm{m}$ radius circular plots in 25 censuses from July 1988 to April 1989 at Myakka River State Park. Treatment means within a column followed by the same letter are not significantly different ( $P>0.05$, Waller-Duncan test).

\begin{tabular}{lcc}
\hline \hline Treatment & Individuals & Species \\
\hline Control & $2.7(2.0)^{\mathrm{a}}$ & $2.0(1.2)^{\mathrm{a}}$ \\
Winter burn & $2.4(1.7)^{\mathrm{ab}}$ & $1.7(1.1)^{\mathrm{ab}}$ \\
Winter chop & $1.2(1.0)^{\mathrm{c}}$ & $1.0(0.8)^{\mathrm{c}}$ \\
Summer burn & $1.9(1.9)^{\mathrm{b}}$ & $1.5(1.2)^{\mathrm{b}}$ \\
Summer chop & $0.2(0.6)^{\mathrm{d}}$ & $0.2(0.5)^{\mathrm{d}}$ \\
\hline
\end{tabular}

wild and 1 prescribed) approximately 2 years apart was not significantly reduced for more than 1 growing season. These results support the need for mechanical treatment to expedite prairie restoration.

Shrub control treatments applied in this study had an acute effect on bird abundance and species composition. Birds were present in the summer burn plots the next day following treatment but were not observed in summer chop plots until approximately 5 months posttreatment. Bird species richness and abundance in winter chop plots stayed lower than in burned and control plots for the duration of this study. One reason for fewer birds in the chopped plots may have been lack of vertical diversity and perches in the habitat. In the burn plots defoliated shrub stems and branches were still standing, providing perches; in the chop plots all the vegetation was flattened, and regrowth was slower. Also, as has been suggested by others (Bendell 1974, Dickson 1981), fire is a natural occurrence with which these bird species have evolved and are accustomed to its effects on vegetation. 
The first birds observed in summer chop plots, and the majority of birds seen in all chopped plots, were eastern meadowlarks (Sturnella magna (L.)), Bachman's sparrows, and other unknown sparrows. Birds such as eastern meadowlarks, Bachman's sparrows, and loggerhead shrikes (Lanius ludovicianus L.), which use open habitats (Terres 1980), were not observed in control plots. Control plots attracted more migrants and also had species such as white-eyed vireos (Vireo griseus (Boddaert)), northern cardinals (Cardinalis cardinalis (L.)), and grey catbirds (Dumetella carolinensis (L.)). These shrub-level inhabitants (Dickson and Segelquist 1979, Terres 1980) were not observed in any treatment plot. Rufous-sided towhees (Pipilo erythrophthalmus (L.)), common yellowthroats, palm warblers (Dendroica palmarum (Gmelin)), and northern mockingbirds (Mimus polyglottos $\mathrm{L}$.) were seen in control plots and all treatments except summer chop plots.

Control plots had the highest mean number of bird species and the highest mean number of individuals. These parameters in the burn plots were similar to control plots. Perch availability, vertical diversity and shrub cover, and height within control and burn plots were similar soon after treatment installation. These habitat features, however, were reduced by chopping. The goal at Myakka River State Park is prairie restoration and to attract Florida prairie inhabitants back into these areas. The appearance of eastern meadowlarks, loggerhead shrikes, and grasshopper sparrows indicated a trend towards the reestablishment of a grassland. A reduction in complexity of vertical habitat structure due to prairie restoration activities should cause a shift in species composition in the avian community and an overall lowcring of species diversity on these treated areas. However, within the dryland prairie of Florida forested habitats associated with the scattered wetlands common to this region should provide a diversity of vegetative structure to support a mixture of grassland and forest bird species.

\section{Literature Cited}

Anderson, S.H. 1980. Habitat selection, succession, and bird community organization. p. 13-26. In: R.M. DeGraaf (tech. coord.). Management of western forests and grasslands for nongame birds. USDA Forest Serv. Gen. Tech. Rep. INT-86.

Bendell, J.F. 1974. Effects of fire on birds and mammals. p. 73-138. In:T.T. Kozlowski and C.E. Ahlgren (eds.). Fire and ecosystems. Academic Press. N.Y.

Bock, C.E., and B. Webb. 1984. Birds as grazing indicator species in southwestern Arizona. J. Wildl. Manage. 48:1045-1049.

Canfield, R.H. 1941. Application of the line interception method in sampling range vegetation. J. Forest. 39:388 394.
Dickson, J.G. 1981. Effects of forest burning on songbirds. p. 67-72. In: G.W. Wood (ed.). Prescribed fire and wildlife in southern forests: Proc. Symp. Belle W. Baruch Forest Sci. Inst. of Clemson University. Georgetown, S.C.

Dickson, J.G., and C.A. Segelquist. 1979. Breeding bird populations in pine and pine-hardwood forests in Texas. J. Wildl. Manage. 43:549-555.

Grelen, H.E. 1975. Vegetative response to twelve years of seasonal burning on a Louisiana longleaf pine site. USDA Forest Serv. So. Forest Exp. Sta. Res. Note SO-192.

Hilmon, J.B., C.E. Lewis, and J.E. Bethune. 1963. Highlights of recent results of range research in southern Florida. Soc. Amer. Forest. Proc. 1962:73-76.

Hughes, R.H., and F.E. Knox. 1964. Response of gallberry to seasonal burning. USDA Forest Serv. Res. Note SE-21.

Johnston, D.W., and E.P. Odum. 1956. Breeding bird populations in relation to plant succession on the piedmont of Georgia. Ecology. $37: 50-62$.

Kale, H.W., II. 1978. Rare and endangered biota of Florida. Vol. 2: Birds. Univ. Presses of Florida. Gainesville.

Kalmbacher, R.S., and F.G. Martin. 1984. Chopping and tebuthiuron effects on saw-palmetto. Soil Crop Sci. Fla. Proc. 43:86-89.

Langdon, O.G. 1981. Some effects of prescribed fire on understory vegetation in loblolly pine stands. p. 143-153. In: G.W. Wood (ed.). Prescribed fire and wildlife in southern forests: Proc. Symp. Belle W. Baruch Forest Sci. Inst. of Clemson Univ., Georgetown, S.C.

Lewis, C.E. 1970. Response to chopping and phosphate on south Florida range. J. Range Manage. 23:276-282.

Moore, W.H. 1974. Some effects of chopping saw-palmetto pineland threeawn range in south Florida. J. Range Manage. 27:101-104.

Myakka River State Park Unit Plan. 1986. Florida Dep. Natur. Resour. Div. Recreation and Parks. Sarasota, Fla.

National Oceanic and Atmospheric Administration. 1987. National Climatic Data Center. Asheville, N.C. Fla. Section. 91:13.

National Oceanic and Atmospheric Administration. 1988. National Climatic Data Center. Asheville, N.C. Fla. Section. 92:13.

Reynolds, R.T., J.M. Scott, and R.A. Nussbaum. 1980. A variable circular plot method for estimating bird numbers. Condor. 82:309-313.

Soil Conservation Service. 1989. 26 ecological communities of Florida. USDA.

Statistical Analysis Institute. 1986. SAS system for linear models. SAS Institute. Cary, N.C.

Szaro, R.C., and R.P. Balda. 1982. Selection and monitoring of avian indicator species: An example from a ponderosa pine forest in the Southwest. USDA Forest Serv. Gen. Tech. Rep. RM-89.

Tanner, G.W., J.M. Wood, R.S. Kalmbacher, and F.G. Martin. 1988. Mechanical shrub control on flatwoods range in south Florida. J. Range Manage. 41:245-248.

Terres, J.K. 1980. Audubon Society encyclopedia of North American birds. A.A. Knopf Inc. N.Y.

Waldrop, T.A., D.H. Van Lear, R.T. Lloyd, and W.R. Harms. 1987. Long-term studies of prescribed burning in loblolly pine forests of the Southeastern Coastal Plain. USDA Forest Serv. Southeastern Forest Exp. Sta. Gen. Tech. Rep. SE-45. 